\title{
ゾルーゲル法によるメソポーラスシリカの形態ならびに表面機能制御
}

\author{
稲田幹, 北條 純一 \\ 九州大学大学院工学研究院応用化学部門, $\bar{T} 819-0395$ 福岡市西区元岡 744.
}

\section{Control of Morphology and Surface Property of Mesoporous Silica by Sol-Gel Method}

\author{
Miki Inada and Junichi Hojo \\ Department of Applied Chemistry, Faculty of Engineering, Kyushu University, 744 Motooka Nishi-ku, Fukuoka 819-0315, Japan.
}

Received August 3, 2007

\begin{abstract}
SYNOPSIS
Silica based mesoporous materials, such as $\mathrm{SiO}_{2}-\mathrm{TiO}_{2}$ and $\mathrm{SiO}_{2}-\mathrm{Al}_{2} \mathrm{O}_{3}$, have attracted increasing attention because of their remarkable acidic and adsorption properties. In this review, we report sol-gel synthesis of mesoporous $\mathrm{SiO}_{2}$ composite which has homogeneous network, such as $\mathrm{Si}-\mathrm{O}-\mathrm{Ti}$, using metal alkoxides as source. In addition, spherical mesoporous $\mathrm{SiO}_{2}$ and $\mathrm{SiO}_{2}-\mathrm{TiO}_{2}$ particles were synthesized by sol-gel method using W/O emulsion under microwave irradiation.
\end{abstract}

KEY WORDS

sol-gel method, mesoporous silica, emulsion, microwave

\section{1 緒 言}

シリカのゾルーゲル反応を利用して，ナノ粒子，繊維，薄 膜等の様々な高次構造制御が可能である. その中でも, 有機 一無機ハイブリッドを利用したメソポーラスシリカに関する 研究は盛んに行われてきた ${ }^{1)}$. メソポーラスシリカは高い比 表面積ならびに制御された細孔構造を有しており, 高機能の 吸着剤や触媒としての利用が期待されている.ゾルーゲル法 により生成するシリカは非晶質であり, シリカネットワーク に様々な金属イオンを導入できることから, 吸着・触媒機能 の制御が可能となる. チタニアあるいはアルミナの添加によ る酸点形成は典型的な例であるが, 酸点形成には異種金属酸 化物をメソポーラスシリカに均一にドープすることが重要で ある ${ }^{2-6)}$.

通常, ゾルーゲル法による生成物はバルク体で得られてお り, 使用するには粉砕が必要である. 実用的には均一サイズ の球状のメソポーラスシリカが望まれるところである. 筆者 らは, メソポーラスシリカの新規形態制御法として, W/O工 マルションを用いた球状化に着目した ${ }^{7)}$. ミセル内殼にシリ カ源を含む水相を用い, 加熱によってゾルーゲル反応を進行 させることにより,ミセルの球状を維持したメソポーラスシ リカが生成する. 加熱法にマイクロ波を用いることにより,
ミセル内殼水相への局所加熱が可能となり, エマルションを 破壊することなく球状粒子が生成する.

本稿では, 金属アルコキシドを用いたゾルーゲル法におけ るメソポーラスシリカへのチタニア, アルミナの導入条件と 比表面積, 酸性度との関係, ならびにマイクロ波加熱を利用 した球状メソポーラスシリカの合成法について紹介する.

\section{2 実験方法}

2.1 チタニア, アルミナ添加メソポーラスシリカの合成 金属アルコキシドを原料としたゾルーゲル法により, チタ ニア, アルミナを添加したメソポーラスシリカを合成した. 合成のフローチャートをFig.1に示す. 原料として, シリカ源 にTEOS $\left(\mathrm{Si}\left(\mathrm{OC}_{2} \mathrm{H}_{5}\right)_{4}\right)$, チタニア源にTEOT $\left(\mathrm{Ti}\left(\mathrm{OC}_{2} \mathrm{H}_{5}\right)_{4}\right)$, アル ミナ源に $\mathrm{Al}\left(\mathrm{OC}_{2} \mathrm{H}_{5}\right)_{3}$, 細孔のテンプレートには陽イオン性界 面活性剤 $\mathrm{C}_{18} \mathrm{TAC}\left(\mathrm{C}_{18} \mathrm{H}_{37}\left(\mathrm{CH}_{3}\right)_{3} \mathrm{NCl}\right)$ を用いた. 出発溶液の基本 組成はモル比でTEOS : $\mathrm{H}_{2} \mathrm{O}: \mathrm{C}_{18} \mathrm{TAC}=1: 20: 0.2$ とし, 反応温 度を $50{ }^{\circ} \mathrm{C}$ とた. 加水分解過程で以下に示す 2 つの添加法を 行うことにより, メソポーラスシリカ複合体の合成を行った. (1) 1 段階プロセス

TEOS と TEOTを同時に添加する方法で, $\mathrm{HCl}$ により $\mathrm{pH}=2$ に調整した $\mathrm{H}_{2} \mathrm{O}$ に界面活性剤を溶解し, $50{ }^{\circ} \mathrm{C} て ゙ 30 \mathrm{~min}$ 擋汼 
(a) one-step process

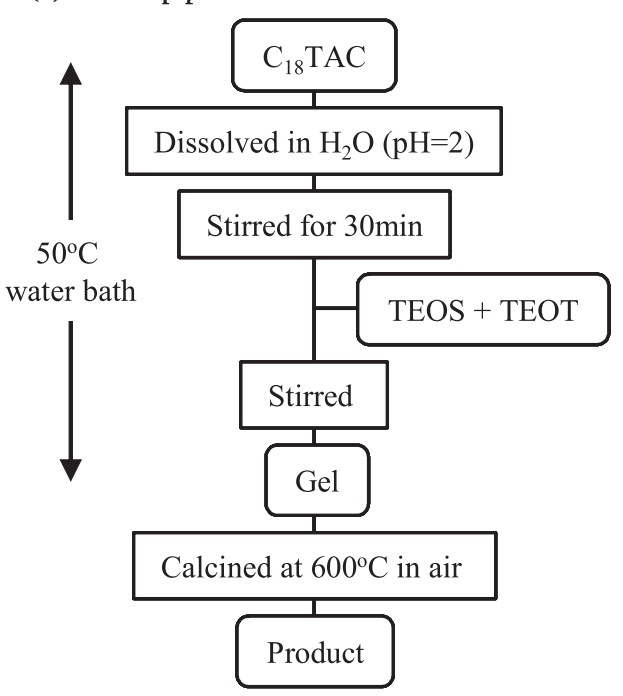

(b) two-step process



Fig.1 Flow charts for synthesis of mesoporous $\mathrm{SiO}_{2}-\mathrm{TiO}_{2}$ by (a) one-step and (b) two-step processes.

した後, TEOSとエタノールで希釈したTEOTを加えた. TEOT は加水分解速度が大きく, 直接添加すると白色沈殿が生成す るため, エタノールで 20 倍程度に希釈した.

(2) 2 段階プロセス

TEOSを部分加水分解させた後に, TEOTあるいは $\mathrm{Al}\left(\mathrm{OC}_{2} \mathrm{H}_{5}\right)_{3}$ を加える方法で, $\mathrm{HCl}$ により $\mathrm{pH}=2$ に調整した $\mathrm{H}_{2} \mathrm{O}$ に TEOS を加え, $50^{\circ} \mathrm{C} て ゙ 30 \mathrm{~min}$ 擋拌することで, 部分加水分解を進行 させた．この溶液に $\mathrm{C}_{18} \mathrm{TAC}$ を溶解した後, エタノール希釈 した TEOT あるいは $\mathrm{Al}\left(\mathrm{OC}_{2} \mathrm{H}_{5}\right)_{3}$ を添加した.

以上のように調整した反応溶液を $50^{\circ} \mathrm{C}$ で摚拌し, 加水分解 を進行させた. テンプレート除去のため, 得られたゲルを空 気中, $600^{\circ} \mathrm{C}$ で仮焼した. 生成物は, $\mathrm{N}_{2}$ 吸着による BET 比表

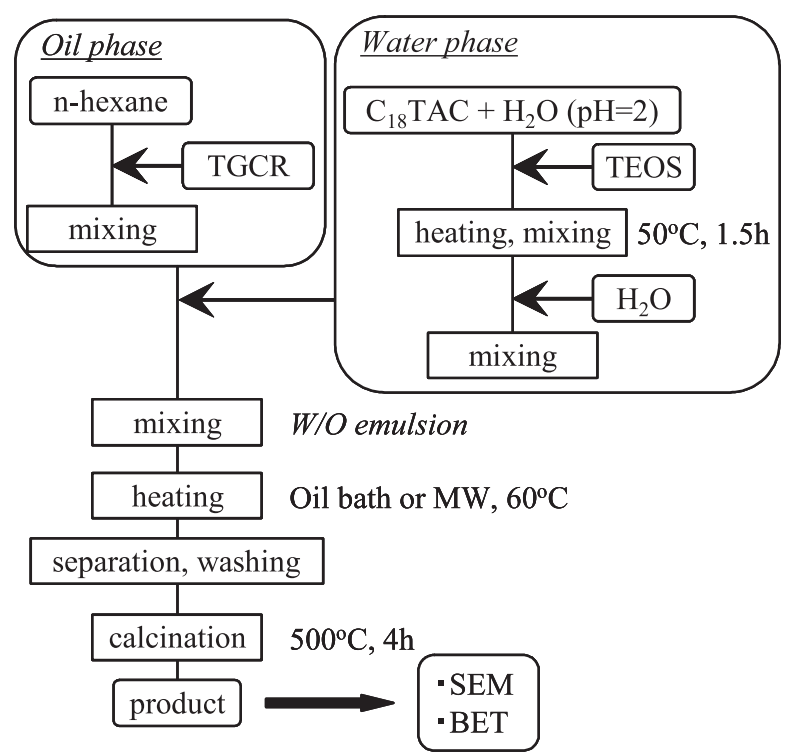

Fig.2 Flow chart for synthesis of spherical mesoporous silica.

面積測定, アミン滴定法による酸性度および酸強度測定によ り評価した.

2.2 球状メソポーラスシリカ, シリカーチタニア複合体の合成

W/Oエマルションを用い, ゾルーゲル法により, 球状メり ポーラスシリカを合成した. 合成フローチャートをFig.2に示 す. シリカ源としてTEOSを, 細孔のテンプレートとして陽 イオン性界面活性剤 $\mathrm{C}_{18} \mathrm{TAC}$ を用いた. 水相の出発組成はモ ル比で TEOS : $\mathrm{H}_{2} \mathrm{O}: \mathrm{C}_{18} \mathrm{TAC}=1: 56: 0.28$ とした. $\mathrm{HCl}$ により $\mathrm{pH}=2$ に調整した $\mathrm{H}_{2} \mathrm{O}$ に $\mathrm{C}_{18} \mathrm{TAC}$ を溶解し, TEOSを加えて 50 ${ }^{\circ} \mathrm{C}$ で $90 \mathrm{~min}$ 擋拌し, TEOSを部分加水分解させを溶液を水相 とした. ヘキサンに乳化剤 (テトラグリセリン縮合リシノレ イン酸エステル (TGCR)) を溶解して調整した油相に, 部分加 水分解したTEOSを含む水相を混合・擋拌し, W/Oエマルショ ンを得た.このエマルションを $60^{\circ} \mathrm{C}$ で加熱し, ミセル内殼の 水相で加水分解を進行させた. 加熱法として, オイルバスを 用いた通常加熱とCEM社のMARS5Xを用いたマイクロ波加 熱を行った. シリカーチタニア系では, 水相の調整時に, $\mathrm{C}_{18} \mathrm{TAC}, \mathrm{TEOS}$ とともに, チタニア源として TEOT を使用し た. TEOT の加水分解速度が TEOSに比べて大きいため, ア セチルアセトンをキャッピング剤に用いて TEOTの加水分解 を抑制した. 反応後, 生成物を分離, 洗浄し, テンプレート 除去のために $500^{\circ} \mathrm{C} て ゙ 4 \mathrm{~h}$ 仮焼した，生成物は，SEMによる 形態観察, $\mathrm{N}_{2}$ 吸着によるBET 比表面積測定により評価した.

\section{3 チタニア, アルミナ添加メソポーラスシリカの 合成と評価}

3.11 段階プロセスと $2 \mathbf{E}$ 階プロセスの比較

シリカーチタニア系のメソ多孔体を合成する場合, TEOS に対して TEOT の加水分解速度が大きいことが問題となる. そこで, TEOS とTEOTの混合に際し, TEOTの1段階添加と 
2段階添加の影響を調查した. 生成物の表面特性をTable 1に, 細孔分布曲線を Fig.3にそれぞれ示す.いずれの生成物も 2-3 $\mathrm{nm}$ のメソ孔を持ち, 比表面積は $1000 \mathrm{~m}^{2} / \mathrm{g}$ 以上を示した. 1 段

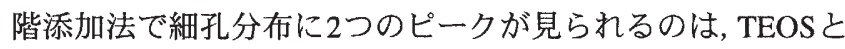
TEOT の加水分解速度の差により, シリカネットワークによ る規則的な細孔の配列が乱れ不均一になったためと考えられ る. 一方, 2 段階添加では 1 つシャープなピークが見られ， メり孔が均一であることが示唆された.

シリカは単体でもわずかに酸性度を示すが, シリカ構造内 にチタニアを添加したところ, 酸性度は大きく向上した (Table 1).これは, Si-O-Tiの形成による新たな酸点の生成に 起因すると考えられる. 1段階添加の場合, 高い酸性度は得 られなかったが，2段階添加を行ったところ，高い酸性度を 示した. これは, 加水分解速度を考慮することで, シリカネッ トワークにチタニアが均一に導入されたためである.

\section{2 各種パラメータの影響}

メソポーラスシリカーチタニアの合成において, 水添加量, テンプレート量, TEOT量の影響を調査したところ, 水添加量 やテンプレート量は比表面積や細孔径に影響するが, Si-O-Ti ネットワークの形成には無関保であることがわかった.一方, TEOT添加量は比表面積・細孔径や酸性度に大きく影響した. 原料の Ti/Si 比に対する生成物の BET 比表面積および細孔径

Table 1 Surface properties of mesoporous $\mathrm{SiO}_{2}-\mathrm{TiO}_{2}$ synthesized by two processes.

\begin{tabular}{cccc}
\hline & $\begin{array}{c}\mathrm{S}_{\mathrm{BET}} \\
\left(\mathrm{m}^{2} / \mathrm{g}\right)\end{array}$ & $\begin{array}{c}\mathrm{d}_{\mathrm{BET}} \\
(\mathrm{nm})\end{array}$ & $\begin{array}{c}\text { Acidity } \\
(\mathrm{mmol} / \mathrm{g})\end{array}$ \\
\hline one-step & 1203 & 2.6 & 8.1 \\
two-step & 1356 & 3.4 & 22.4 \\
\hline
\end{tabular}

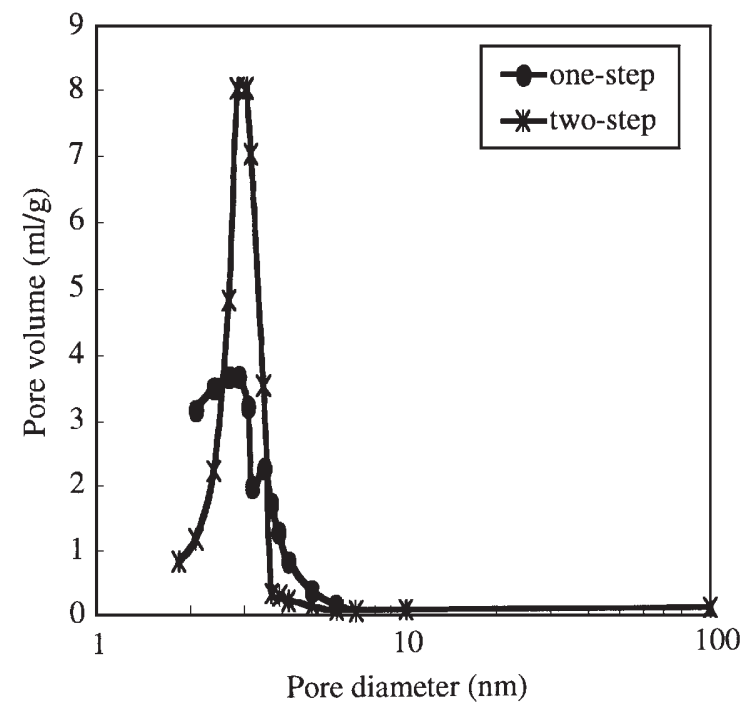

Fig.3 Pore size distribution of mesoporous $\mathrm{SiO}_{2}-\mathrm{TiO}_{2}$ synthesized by one-step and two-step processes.
を Table 2 に示す. すべての試料で $1000 \mathrm{~m}^{2} / \mathrm{g}$ 以上の比表面積 を示したが, TEOT添加量の増加に伴い比表面積は滅少し, 細 孔径は $3.4 \mathrm{~nm}$ から $2.0 \mathrm{~nm}$ に隇少した. 異なる $\mathrm{pKa}$ を持つ指示 薬で酸性度を測定したところ(Fig.4)，いずれの指示薬を用い た場合も, TEOT 添加量が 0.02 で酸性度は最大を示した。 シ リカは $\mathrm{Si}$ 周りにO 原子が4配位で安定であるのに対し, チ夕 ニアは酸素6配位が安定である.これらのことから, TEOT添 加量 0.02 まではSi-O-Ti 結合が形成されたが，それ以上では チタニアが分離生成したと考えられる.

シリカーアルミナ系でも, $\mathrm{A} 1$ のエトキシドを用いて同様の プロセスで高比表面積のメソ多孔体が得られた. Fig.5に Al/ $\mathrm{Si}$ 比に対する酸性度変化を示す．いずれの指示薬でも, $\mathrm{Al} / \mathrm{Si}$ 比が高くなるほど酸性度が高くなった，アルミナは酸素4配 位構造を取り得るため, かなりの高濃度までシリカネット ワークに組込むことが可能であった.

\section{4 球状メソポーラスシリカ, シリカーチタニア複合体の 合成と評価}

4.1 球状メソポーラスシリカの合成

マイクロ波は水に対して選択的に吸収され，急速加熱が可 能である.この特性を利用して, W/Oエマルション法により

Table 2 Specific surface area and pore diameter at different $\mathrm{Ti} / \mathrm{Si}$ molar ratio.

\begin{tabular}{ccc}
\hline $\mathrm{Ti} / \mathrm{Si}$ & $\begin{array}{c}\mathrm{S}_{\mathrm{BET}} \\
\left(\mathrm{m}^{2} / \mathrm{g}\right)\end{array}$ & $\begin{array}{c}\mathrm{d}_{\mathrm{BET}} \\
(\mathrm{nm})\end{array}$ \\
\hline 0.01 & 1356 & 3.4 \\
0.02 & 1130 & 3.1 \\
0.1 & 1178 & 2.7 \\
1 & 1096 & 2 \\
\hline
\end{tabular}

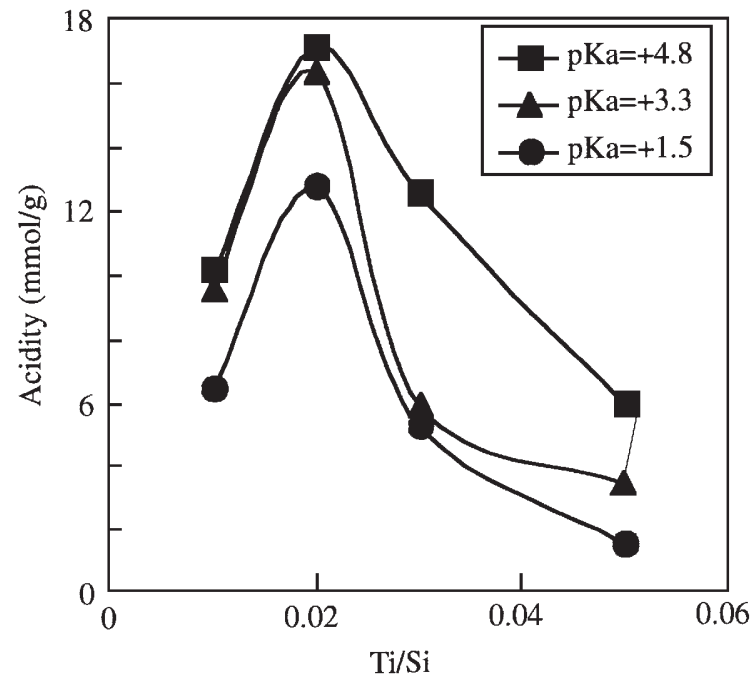

Fig.4 Change in acidity with $\mathrm{Ti} / \mathrm{Si}$ molar ratio. 


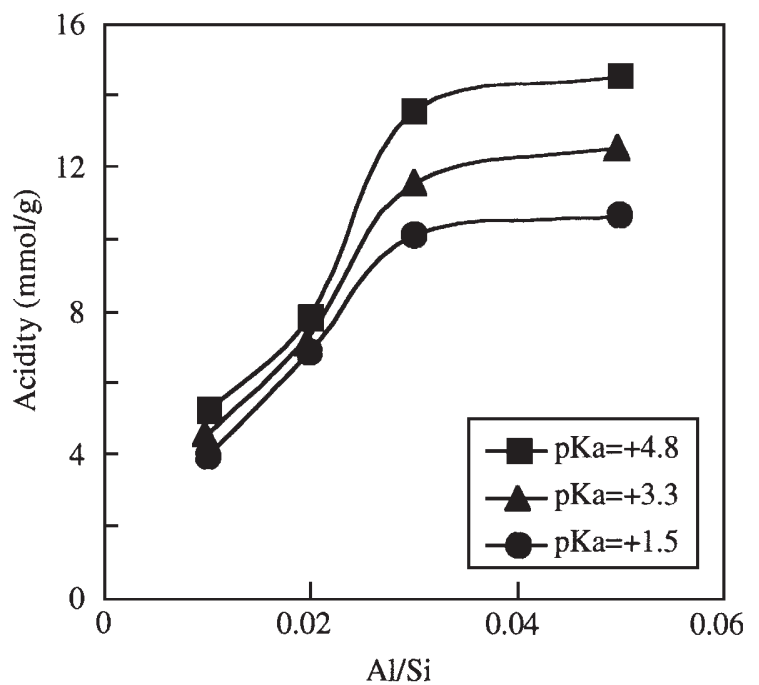

Fig.5 Change in acidity with $\mathrm{Al} / \mathrm{Si}$ molar ratio.
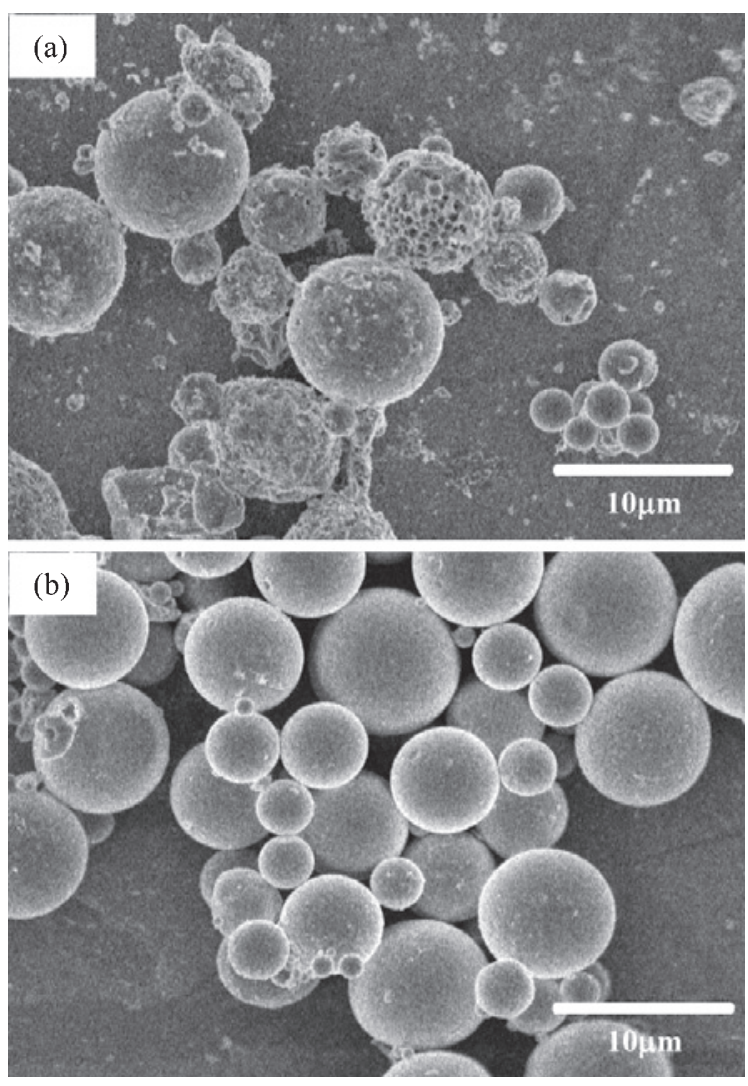

Fig.6 SEM images of products by (a) conventional heating method and (b) microwave heating method.

球状メソポーラスシリカを合成した，通常法，マイクロ波法 のいずれの加熱法でも, BET 比表面積 $840 \mathrm{~m}^{2} / \mathrm{g}$, 平均細孔径 2-3 nmであったことから, 生成物はメソポーラスであること が示唆された。このことは, W/Oエマルションの内殼水相に おいて, $\mathrm{C}_{18} \mathrm{TAC}$ お゙テンプレートとして機能したことを示して いる. 生成物の SEM 写真を Fig.6に示す. マイクロ波加熱法
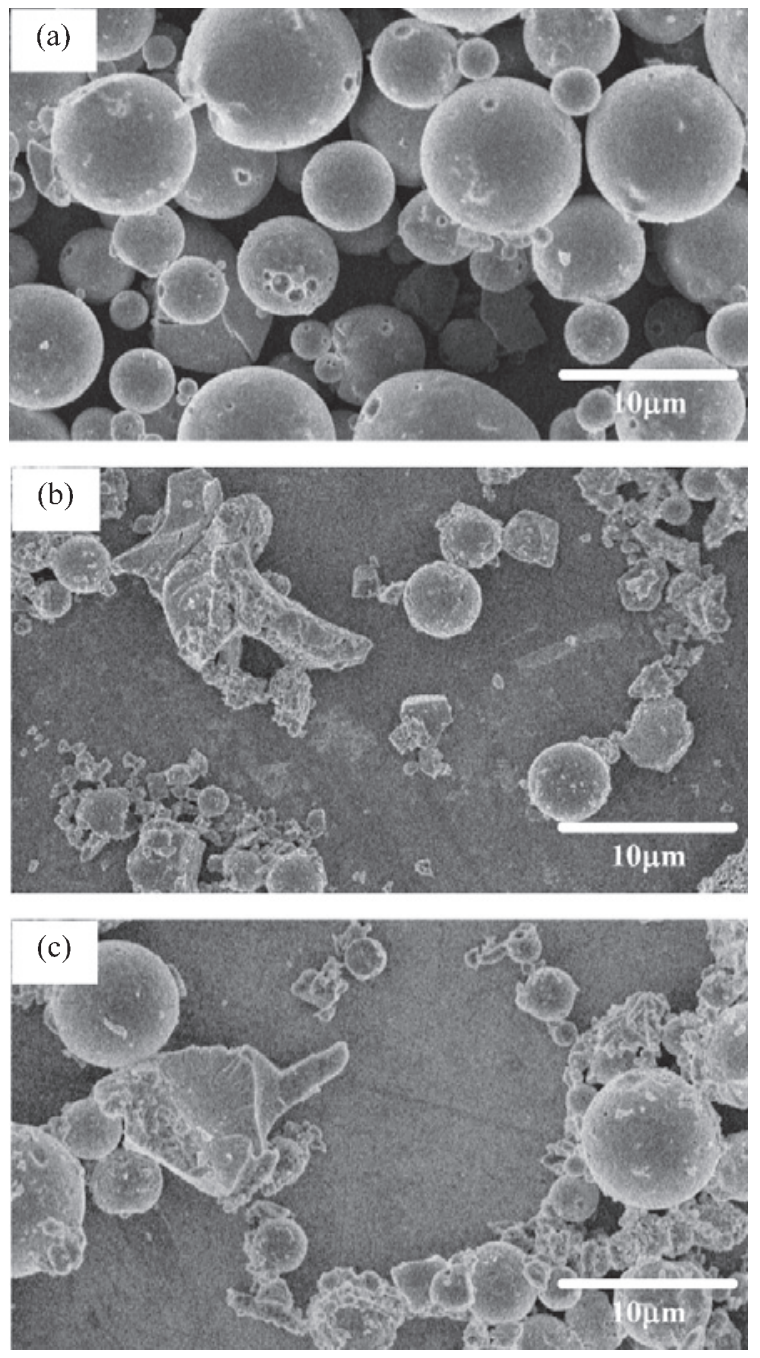

Fig.7 SEM images of products in $\mathrm{SiO}_{2}-\mathrm{TiO}_{2}$ system: (a) $\mathrm{Ti} / \mathrm{Si}=$ 0.1 , (b) $\mathrm{Ti} / \mathrm{Si}=0.5$, (c) $\mathrm{Ti} / \mathrm{Si}=1.0$.

では滑らかな表面を持った球状粒子が観察されたが, 通常加 熱法では不定形な粒子で表面が荒れていた.これらのことは, マイクロ波による急速かつ選択的加熱が球状粒子生成に有効 であることを示している. 油相の溶媒であるへキサンは水に 比べて誘電率が低いため, マイクロ波加熱によって内殼水相 が選択的に加熱される. 高温でW/Oエマルションは不安定に なるが, マイクロ波加熱では内殼水相のみが加熱されるため, W/Oエマルションの球状形態が維持され, 球状メソポーラス シリカが生成したと考えられる.

4.2 球状メソポーラスシリカーチタニア複合体の合成

Fig.7にシリカーチタニア系生成物の SEM写真を示す. Ti/ $\mathrm{Si}=0.1$ では BET 比表面積 $800 \mathrm{~m}^{2} / \mathrm{g}$, 平均細孔径 2-3 nm であ り, シリカーチタニア系でも球状メソポーラス粒子が生成し た. Ti 量が増加すると球状形態が崩れる傾向が見られた。球 状メソポーラスシリカ合成においてTEOS 量を増やした場合 も球状形態が崩れたことから, 原料組成の変化によって出発 溶液のW/Oエマルションが不安定になったと考えられる. 


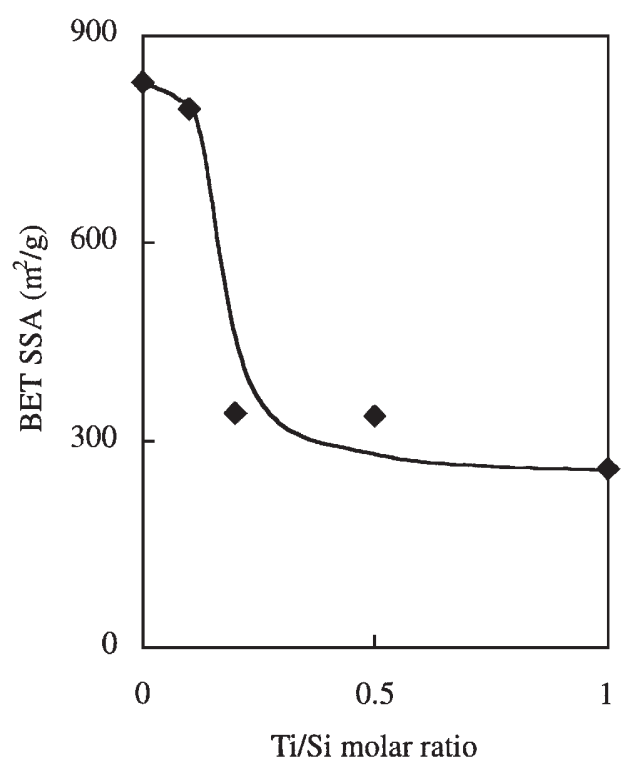

Fig.8 Change in specific surface area with Ti/Si molar ratio.

Fig.8に Ti/Si 比に対する比表面積変化を示す. Ti/Si>0.1 では $\mathrm{Ti} / \mathrm{Si}$ 比の増加に伴い比表面積が滅少した. TEOTのキャッピ ング剤であるアセチルアセトンがメソポーラス構造の形成に 影響したと考えられる. また, 酸性度はTi/Si=0.1 で最大を示 し, それ以上では減少した。 これらのことから, 上節と同様 に, Ti量が少ない場合はTiがシリカネットワークに組み込ま れて Si-O-Ti 結合を形成するが，一定値より多くなるとチ夕 ニアとして分離析出し, 酸性度が低下したと考えられる。

\section{5 まとめ}

ゾルーゲル法によるメりポーラスシリカの合成において, シリカ源であるTEOSの加水分解を考慮することにより，チ タニアやアルミナをシリカネットワークに組み込んだメり ポーラス複合体を得ることができた. チタニア添加の場合, 原料である TEOTの加水分解速度が大きいために, 高 Ti/Si 比 ではチタニアが分離析出したが， $\mathrm{Ti} / \mathrm{Si}=0.02$ までは $\mathrm{Si}-\mathrm{O}-\mathrm{Ti}$ 結合が均一に形成され，生成物は高い酸性度を示した。一方， アルミナ添加の場合は $\mathrm{A} 1 / \mathrm{Si}$ 比が高くなるほど酸性度も向上 し, 高濃度においてもA Alがシリカネットワークに組み込まれ ることが示唆された.これらのことは, 金属酸化物の酸素配 位数の違いにより,生成する複合体の特性が変化することを
如実に示している.

マイクロ波を用いたW/Oエマルション法により,メソポー ラスシリカの球状化を達成できた. 生成物の比表面積は 800 $\mathrm{m}^{2} / \mathrm{g}$ 程度であったことから, W/Oエマルションの内殼水相に おいて $\mathrm{C}_{18} \mathrm{TAC}$ がテンプレートとして機能し, メソポーラス 構造が構築できた. 通常加熱とは異なり, マイクロ波加熱で は球状粒子のみが生成し, マイクロ波加熱の優位性が示され た.

以上,ゾルーゲル法によるメソポーラスシリカ合成におい て, 加水分解の制御により金属酸化物を均一に導入し, w/O エマルションを用いることで球状化が可能であることを明ら かにした.

\section{文献}

1) C.T.Kresge, M.E.Leonowicz, W.J.Roth, J.C.Vrtuli and J.S.Beck: "Ordered Mesoporous Molecular Sieves Synthesized by a Liquid-Crystal Template Mechanism", Letter to Nature, 359(1992)710-713.

2) S.Zheng, L.Gao, Q.Zhang and J.Guo: "Synthesis, characterization and photocatalytic properties of titaniamodified mesoporous silicate MCM-41", J. Mater. Chem., 10 (2000) 723-727.

3) S.Zheng, L.Gao, Q.Zhang, W.Zhang and J.Guo: "Preparation, characterization and photocatalytic properties of singly and doubly titania-modified mesoporous silicate MCM- 41 by varying titanium precursors", J. Mater. Chem., 11 (2001)578583.

4) X.Y.Li, M.Uehara, N.Enomoto and J.Hojo: "Process Factors on Sol-Gel Synthesis of Ti-Doped Mesoporous Silica", Trans. Mater. Soc. Jpn., 26(2) (2001)499-502.

5) X.Y.Li, M.Uehara, N.Enomoto and J.Hojo: "Synthesis of Titania-Doped Mesoporous Silica and Its Gas Adsorbability", J. Ceram. Soc. Jpn., 109(10)(2001)818-822.

6) N.Enomoto, K.Kawasaki, M.Yoshida, X.Y.Li, M.Uehara and J.Hojo: "Synthesis of mesoporous silica modified with titania and application to gas adsorbent", Solid State Ionics, 151(2002) 171-175.

7) M.Inada, A.Nishinosono, K.Kamada, N.Enomoto and J.Hojo: "Microwave-assisted Sol-gel Process for Production of Spherical Mesoporous Silica Materials", J. Mater. Sci., in Press. 